\title{
Introduction: Socialism and History
}

"We Are All Socialists Now: The Perils and Promise of the New Era of Big Government" ran the provocative cover of Newsweek on 11 February 2009. A financial crisis had swept through the economy. Several small banks had failed. The state had intervened, pumping money into the economy, bailing out large banks and other failing financial institutions, and taking shares and part ownership in what had been private companies. The cover of Newsweek showed a red hand clasping a blue one, implying that both sides of the political spectrum now agreed on the importance of such state action.

Although socialism is making headlines again, there seems to be very little understanding of its nature and history. The identification of socialism with "big government" is, to say the least, misleading. It just is not the case that when big business staggers and the state steps in, you have socialism. Historically, socialists have often looked not to an enlarged state but to the withering away of the state and the rise of nongovernmental societies. Even when socialists have supported state intervention, they have generally focused more on promoting social justice than on simply bailing out failing financial institutions.

A false identification of socialism with big government is a staple of dated ideological battles. The phrase "We are all socialists now" is a quotation from a British Liberal politician of the late nineteenth century. Sir William Harcourt used it when a land reform was passed with general acceptance despite having been equally generally denounced a few years earlier as "socialist." Moreover, Newsweek's cover was not the first echo of Harcourt's memorable phrase. On 31 December 1965, Time magazine had quoted Milton Friedman, a monetarist economist who later helped to inspire the neoliberalism of the 1980s and '90s, as saying, "We are all Keynesians now." During the twentieth century, conservative and neoliberal ideologues encouraged "red scares" by associating not just Soviet communism but also socialism, progressivism, and Keynesianism with totalitarianism. All kinds of benevolent and ennobling projects were thus decried. The Appalachian Trail was the first completed national scenic trail in the United States. It is managed by a volunteer-based organization and maintained by trail clubs and multiple partnerships. It houses and protects some two thousand rare and endangered species of plant and 
animal life. This trail was first proposed in 1921 by Benton MacKaye, a progressive and an early advocate of land preservation for ecological and recreational uses. ${ }^{1}$ MacKaye's inspiring vision was of a hiking trail linking self-owning communities based on cooperative crafts, farming, and forestry and providing inns and hostels for city dwellers. Critics complained that the scheme was Bolshevist.

The Bolshevik Revolution and the cold war helped entrench particular ways of thinking about socialism. Socialism became falsely associated with state ownership, bureaucratic planning, and the industrial working class. As a result, before the financial crisis, socialism appeared to some to be disappearing into the history books. There were numerous empty celebrations of the triumph of capitalism. The fall of the Berlin Wall in 1989 became a popular marker for the end of "real socialism." Few communist states remained, and they were communist in little more than the official title of the ruling political party. Socialism, progressivism, and

rebranded itself as "New Labour." The party's leaders accepted much of the neoliberal critique of the Keynesian welfare state. They explicitly rejected old socialist "means," including state ownership, bureaucratic planning, and class-based politics. Moreover, although they suggested that they remained true to socialist "ends," this change in means entailed a shift in ends, with, for example, the greater role given to markets pushing the concept of equality away from equality of outcome and toward equality of opportunity. ${ }^{2}$

Perhaps an adequate response to current and future problems depends on a rejection of the caricatures of old ideological battles. Perhaps we would be better placed to consider possible responses to problems-such as those posed by the financial crisis and ecological preservation-if we had a more accurate understanding of the nature and history of socialism. Perhaps we should treat the pulling down of the Berlin Wall not as a sign of the triumph of capitalism but as the end of the conceptual dichotomy that had pitted socialism against capitalism. ${ }^{3}$ Perhaps we should see the collapse of real socialism not as justifying an empty neoliberal triumphalism in which global capitalism has swept all before it but as an opportunity to reconsider the history of socialism.

${ }^{1}$ L. Anderson, Benton MacKaye: Conservationist, Planner, and Creator of the Appalachian Trail (Baltimore: Johns Hopkins University Press, 2002).

2 M. Bevir, New Labour: A Critique (London: Routledge, 2005), esp. pp. 54-82.

${ }^{3}$ M. Bevir and F. Trentmann, eds., Critiques of Capital in Modern Britain and America: Transatlantic Exchanges, 1800 to the Present Day (Basingstoke, UK: Palgrave Macmillan, 2002); and M. Bevir and F. Trentmann, eds., Markets in Historical Contexts: Ideas and Politics in the Modern World (Cambridge: Cambridge University Press, 2004). 
trieve lost socialist voices, their histories, and their continuing legacy and relevance. In this book, I rethink socialism by looking back to the late nineteenth century, before ideological lines became hardened by political parties and cold-war warriors. I explore creative exchanges between socialism and other traditions, including popular radicalism, liberal radicalism, and romanticism. I show that socialism was closely associated with progressive justice, radical democracy, and a new life. In doing so, I hope to offer a fruitful history that will inspire further research. And I hope also to retrieve neglected socialist ideas that might inspire political action today. The era of state ownership, bureaucratic planning, and the industrial working class may perhaps be behind us. But even if it is, many socialist ideas remain viable and exciting-perhaps necessary, definitely worth fighting for.

\section{HISTORIOGRAPHY}

My account of the making of British socialism participates in a historiographical revolution. Just as the end of a simplistic dichotomy between socialism and capitalism makes it possible to retrieve alternative socialist pasts, so rejecting that dichotomy contributes to the rise of new ways of narrating those pasts. The old historiography suggested that socialism arose as the working class became conscious of itself as a class. Historians told the story of workers and their socialist allies reacting to the rise of capitalism by founding political parties, taking power, and building socialist and welfare states. Ideas generally appeared as mere reflections of socioeconomic developments. Today, however, political events, social movements, and theoretical arguments have all combined to dismantle the old historiography. Historians have adopted more fluid concepts of socialism and demonstrated a greater concern with the role of ideas in the construction of social and political practices. They point the way to a new historiography that shows how people actively made socialism by drawing on diverse traditions to respond to dilemmas and to inspire new practices. This chapter discusses this historiographical revolution as it relates to the making of British socialism.

The old historiography emerged in the late nineteenth century alongside the socialist movement, and it remained largely unchallenged until the 1980s. The old historiography attracted Marxists, laborists, and progressives, ranging from G.D.H. Cole to the Hammonds and on, most famously, to Eric Hobsbawm and E. P. Thompson. ${ }^{4}$ These historians told

${ }^{4}$ On non-Marxist traditions of social history, see M. Taylor, "The Beginnings of Modern British Social History,” History Workshop 43 (1997): 155-76. 
a unified and linear story about capitalism and its socialist critics. They argued that capitalism possessed an innate, largely natural trajectory defined by its inner laws. Initial opposition to capitalism took the form of a Luddite resistance, which was soon exposed as naive. ${ }^{5}$ Socialists and workers had to learn the nature of a capitalist society that had arisen independently of their beliefs and actions. As the workers caught up with the reality of capitalism, so they developed class consciousness. ${ }^{6}$ Workingclass consciousness appeared and developed through Chartism, the trade unions, the socialist movement, the Labour Party, and the welfare state. This old historiography thus defined a clear research agenda around the topics of class, production, trade unions, the Labour Party, and the central state as an agent of socioeconomic transformation.

While the old historiography sometimes drew on a materialism and determinism associated with Marxism, it also fitted easily into general accounts of the Victorian age as a time of unprecedented growth. Most social historians believed that the Industrial Revolution brought a rapid entry into modernity during the early nineteenth century. The Industrial Revolution marked a clear break with traditional society. It introduced a world of factories, the bourgeoisie, political reform, an organized working class, and thus class conflict and class accommodation. ${ }^{7}$ Even after Thompson encouraged social historians to emphasize human agency in contrast to a crude Marxist determinism, they continued to study the ways in which people had made this modern world. Thompson himself studied "the poor stockinger, the Luddite cropper, the obsolete handloom weaver, the utopian artisan," not only to rescue them "from the enormous condescension of posterity," but also to show how they made a modern, organized, and politically conscious working class. ${ }^{8}$ Although Thompson emphasized the role of Protestantism, he presented workingclass agency as a response to more or less pure experiences of socioeconomic reality. The turn to agency thus left the old historiography intact even as it broadened the research agenda to encompass more subjective aspects of the past.

${ }^{5}$ E. Hobsbawm, Primitive Rebels: Studies in Archaic Forms of Social Movement in the $19^{\text {th }}$ and $20^{\text {th }}$ Centuries (Manchester, UK: Manchester University Press, 1959).

${ }^{6}$ E. Thompson, The Making of the English Working Class (Harmondsworth, UK: Penguin, 1981).

${ }^{7}$ A. Briggs, The Age of Improvement, 1783-1867 (London: Longman, 1959); G. Kitson Clark,

Origins of Modern English Society, 1780-1880 (London: Routledge, 1969); and G. Young, Victorian England: Portrait of an Age (London: Oxford University Press, 1936).

${ }^{8}$ E. Thompson, Making of the English Working Class, p. 12. 
Challenges to the old historiography reflected both the limitations and the successes of Thompson's intervention. Historiography still privileged a teleological narrative of the rise of the working class, and it still centered on topics such as class, production, unions, socialist parties, and the central state. It thus seemed unable to extend itself to cover widespread changes in the social and political landscape, including deindustrialization, neoliberalism, identity politics, and the new social movements. The forward march of labor had come to an abrupt halt. ${ }^{9}$ Of course, Marxist historians had long grappled with the failure of the working class to fulfill its revolutionary role; they tried to explain this failure by appealing to theories about the peculiar nature of British society, social control, and hegemony. ${ }^{10}$ By the 1980 s, however, the changing social and political landscape posed a more general dilemma for social historians. The dilemma was that the theoretical bases of the old historiography - with its focus on class, production, trade unions, political organization, and the state-appeared more and more implausible as the dominant story of modernity. The theory lurking behind much social history had failed. Some social historians responded to this dilemma by rejecting theory. Thompson conflated his turn to agency with a rhetorical dismissal of theory in favor of an empirical focus on people's experiences of the past. ${ }^{11}$ Other historians turned to new theories, including many that treated language and ideas as relatively autonomous from the development of capitalism.

Parallel challenges to the old historiography arose out of the very successes of Thompson's intervention. Thompson's success in conferring voice and agency on hidden figures of the past inspired numerous historians. Thompson himself echoed an idealized view of a robust, masculine working class engaged in public bodies and didactic self-improvement. Yet, many of the historians he inspired began to retrieve other voices. For a start, even when historians stuck with the male working class, they often shifted their attention from production to consumption. Historians explored the voices of workers interested in the music hall, football,

${ }^{9}$ For an attempt to adapt the old historiography to deal with this difficulty, see E. Hobsbawm et al., The Forward March of Labour Halted (London: New Left Books, 1981).

ing Men: Studies in the History of Labour (London: Weidenfeld and Nicolson, 1964), pp. 272-315; T. Nairn, “The Fateful Meridian,” New Left Review 60 (1970): 3-35; G. Stedman Jones, Outcast London: A Study in the Relationship between Classes in Victorian Society (Oxford: Oxford University Press, 1971); and S. Hall, "The Great Moving Right Show," in The Politics of Thatcherism, ed. S. Hall and M. Jacques (London: Lawrence and Wishart, 1980), pp. 19-39.

${ }^{11}$ E. Thompson, "The Poverty of Theory; or, An Orrey of Errors," in The Poverty of Theory and Other Essays (London: Merlin Press, 1978), pp. 1-210. 
and private leisure activities. ${ }^{12}$ In addition, this interest in sites of consumption recast the study of cultural and political identities. ${ }^{13}$ Historians explored consumption in part because they had become interested in voices other than those of the male working class. New social movements helped shift attention from the factory floor to the family household, the department store, and the imperial museum. Historians explored the voices of women, gays, and colonial subalterns. In doing so, moreover, they pointed to frequent contrasts and tensions between these people and male workers. Joan Scott explicitly argued that the Victorian working class was a masculine construction defined in contrast to a middle class that was accordingly given a feminine identity. ${ }^{14} \mathrm{~A}$ new generation of imperial historians highlighted the racist elements in movements for social and political reform. ${ }^{15}$ A greater awareness of consumption, gender, sexuality, and ethnicity undermined the old historical narrative of the working class spearheading demands for the people's rights and interests along the path to industrial modernity and socialist government. It increased the appeal of new theories that gave a greater autonomy and role to discourses and beliefs.

The transformation of social history continued throughout the 1990s, and it had important consequences for the study of socialism. The greater attention paid to language and ideas spread to the history of socialist thought. The rise of new topics such as gender encouraged a more fluid concept of socialism. Today, therefore, socialism often appears less as the natural outcome of workers' reacting to the prior formation of capitalism and more as a contingent and variegated cluster of political theories.

Historians of socialism now pay more attention to language and ideas. They are less ready to accept that socioeconomic changes necessarily lead to class consciousness, recognition of the social causes of social evils, and so laborism and socialism. Instead, they look more closely at language and the written evidence of radical movements in order to recover people's beliefs. One of the earliest and most prominent examples was

${ }^{12}$ P. Bailey, Popular Culture and Performance in the Victorian City (Cambridge: Cambridge University Press, 1998); and C. Waters, British Socialists and the Politics of Popular Culture, 1884-1914 (Manchester, UK: Manchester University Press, 1990).

${ }^{13}$ J. Walkowitz, City of Dreadful Delight (Chicago: University of Chicago Press, 1992); and E. Rappaport, Shopping for Pleasure: Women in the Making of London's West End (Princeton, NJ: Princeton University Press, 2000).

${ }^{14} \mathrm{~J}$. Scott, Gender and the Politics of History (New York: Columbia University Press, 1988). Also see A. Clark, The Struggle for the Breeches: Gender and the Making of the British Working Class (Berkeley: University of California Press, 1995).

${ }^{15}$ A. Burton, Burdens of History: British Feminists, Indian Women, and Imperial Culture, $1865-1915$ 
Gareth Stedman Jones's study of Chartism. ${ }^{16}$ The old historiography portrayed Chartism as the first expression of the class consciousness of the workers; the Chartists broke with popular Luddite forms of resistance and initiated a modern social outlook. In contrast, Stedman Jones treated the language of protest as relatively autonomous from the development of capitalism. He suggested that the language of the Chartists pointed to a political movement as much as a social one. Chartism was less the inauguration of a modern working class looking forward to the twentieth century than the end of a popular radicalism reaching back to the eighteenth century.

When other social historians have examined language and ideas, they too have stressed continuity and populism. Intellectual historians of the eighteenth century have explored the diverse, complex languages within which social theorists and economists responded to the rise of capitalism, commercialism, and market society. ${ }^{17}$ Historians of radicalism and socialism have then traced the continuing legacy of these languages in the nineteenth century. Soon after Stedman Jones traced continuities through the Chartists, Greg Claeys did something similar for the Owenites and the radical economists. ${ }^{18}$ Other historians traced continuities between eighteenth-century ideas and liberal radicalism, thereby highlighting the overlaps and continuities between the Chartists, Owenites, and later liberal radicals. ${ }^{19}$ It now seems clear that the early critics of capitalism drew on diverse strands of radicalism that resembled eighteenth-century republicanism at least as much as they resembled twentieth-century socialism. Even the socialism of the 1880s, 1890s, and early years of the Labour Party echoed themes drawn from popular and liberal radicalism. ${ }^{20}$ The continuity between eighteenth-century republicanism and nineteenth-

${ }^{16}$ G. Stedman Jones, "Rethinking Chartism," in Languages of Class: Studies in English Working-Class History, 1832-1982 (Cambridge: Cambridge University Press, 1983), pp. 90-178.

17 J. Pocock, Virtue, Commerce, and History: Essays on Political Thought and History, Chiefly in the Eighteenth Century (Cambridge: Cambridge University Press, 1985); and D. Winch, Adam Smith's Politics (Cambridge: Cambridge University Press, 1978).

18 G. Claeys, Machinery, Money, and the Millennium: From Moral Economy to Socialism, 1815-60 (Princeton, NJ: Princeton University Press, 1987), and Citizens and Saints: Politics and Anti-politics in Early British Socialism (Cambridge: Cambridge University Press, 1989).

19

(Cambridge: Cambridge University Press, 1991); and E. Biagini, ed., Citizenship and Community: Liberals, Radicals and Collective Identities in the British Isles, 1865-1931 (Cambridge: Cambridge University Press, 1996).

20 J. Lawrence, "Popular Radicalism and the Socialist Revival in Britain," Journal of British Studies 31 (1992): 163-86; and D. Tanner, "The Development of British Socialism, 1900-1918," Parliamentary History 16 (1997): 48-66. 
century radicalism appears most clearly in a type of populism. Historians now suggest that the Chartists and Owenites thought less in terms of modern social classes than of the people. Some historians argue that "the people" or "demos" provided the main frame of collective identity for workers throughout the nineteenth century. ${ }^{21}$

Historians of socialism also now pay more attention to topics associated with consumption, leisure activities, gender, postcolonialism, and race. Studies of these topics in the early and mid-nineteenth century add nuance and detail to accounts of the persistence of eighteenth-century republicanism and related populist languages. For a start, historians have returned to the idea of civil society as a relatively autonomous space capable of fostering toleration and difference through voluntary associations. They have retrieved radical visions, akin to Thomas Paine's, of a vibrant civil society and a minimal state. ${ }^{22}$ They have shown how cooperators and radicals embraced policies such as free trade in the hope of strengthening their own autonomy and that of a broader civil society against commercial capitalism..$^{23}$ Radicals often directed their collective action not to the state but to self-governance and the reform of society from within. Historians have thus shown how consumption and leisure acted as sites of social identity, contest, and reform. In addition, historians have explored identities that prevented class from simply subsuming populist concepts. Class appears as just one identity, created and maintained in tandem with others. Historians have not limited themselves here to identities and categories tied to gender, ethnicity, and sexuality. They have also paid more attention to the impact of religious, aesthetic, and patriotic beliefs on socialist politics. ${ }^{24}$

Victorian social history has been energized by the new interest in ideas and by the rise of new topics. However, the new historiography leaves significant questions largely unaddressed. It may even appear to be little more than a series of particular insights and interests, lacking an overarching theory and narrative. The interest in ideas has created a greater

${ }^{21}$ P. Joyce, Visions of the People: Industrial England and the Question of Class (Cambridge: Cambridge University Press, 1991); and J. Vernon, Politics and the People: A Study in English Political Culture (Cambridge: Cambridge University Press, 1993).

${ }_{22}$ J. Keane, "Despotism and Democracy: The Origins and Development of the Distinction between Civil Society and the State, 1750-1850," in Civil Society and the State, ed. J. Keane (London: Verso, 1988), pp. 35-71. Also see G. Claeys, Thomas Paine: Social and Political Thought (London: Unwin Hyman, 1989).

${ }^{23}$ F. Trentmann, Free Trade Nation (Oxford: Oxford University Press, 2008).

${ }^{24}$ See respectively S. Yeo, "A New Life: The Religion of Socialism in Britain, 18831896," History Workshop 4 (1977): 5-56; I. Britain, Fabianism and Culture: A Study in British Socialism and the Arts, c. 1884-1918 (Cambridge: Cambridge University Press, 1982); and P. Ward, Red Flag and Union Jack: Englishness, Patriotism and the British Left, $1881-1924$ 
awareness of continuities running from eighteenth-century republicanism through the radical movements of the mid-nineteenth century and beyond. But the presence of these continuities raises questions about how and when nineteenth-century radicalism fed into twentieth-century socialism. Of course, socialism continued to overlap considerably with both popular and liberal radicalism. Nonetheless, by the early twentieth century, Britain was home to a range of Marxist groups, other avowedly socialist and anarchist groups, and a Labour Party that combined some of these groups with the trade unions. How was British socialism made in the late nineteenth century? How are we to explain the discontinuities as well as the continuities with earlier radical ideas and movements? Here the new studies of topics such as consumption, gender, and patriotism are of only limited use. They impressively expand our understanding of the ways in which socialism interacted with other ideas and activities, but they arguably lose sight of British socialism as a movement. They focus on a particular theme in socialism, rather than the rise and shape of the socialist movement as a whole. Inevitably, they fragment the ideas and activities of socialist groups. What general narrative should we tell about the making of British socialism? What aggregate concepts best explain the rise of the British socialist movement out of mid-nineteenth-century radicalism? This book aims to provide a general account of the making of British socialism in continuity and discontinuity with earlier radicalisms.

\section{THEORY}

The new historiography needs aggregate concepts that can cover its fragmented studies of particular topics and that allow for historical continuity and discontinuity. The task of building these aggregate concepts is in part a theoretical one. ${ }^{25}$ Historians need theories that avoid the determinism and essentialism of the old historiography. Their concepts cannot reduce socialist thought to socioeconomic terms. Nor can their concepts rely on appeals to a "true socialism" or class consciousness. Instead, their concepts should allow that socialism is diverse and contingent. There may seem to be a tension here. On the one hand, aggregate concepts necessarily clump particular beliefs and events together; they suggest a pattern, privileging some features and some cases while neglecting others; and so they might seem inevitably to elide diversity and contingency. On the other hand, the more historians refuse all aggregate concepts and focus instead on the diversity and contingency of particular cases and topics, the less able they

\footnotetext{
${ }^{25}$ For the philosophical groundwork of this theory, see M. Bevir, The Logic of the His-
} tory of Ideas (Cambridge: Cambridge University Press, 1999). 
are to explain what happened in the past. Clearly the solution lies with aggregate concepts that avoid determinism and essentialism.

Unfortunately, the vigor and sophistication of the new historiography has not been replicated in new historical theories. On the contrary, historians have often retreated into a naive empiricism that dismisses the need for theory, or they have used structuralist and post-structuralist tropes that merely displace determinism and essentialism into the linguistic sphere. ${ }^{26}$ When Thompson conflated his turn to agency with a dismissal of all theory, he was explicitly attacking the structuralist Marxism of Louis Althusser. ${ }^{27}$ Other historians, equally misleadingly, have tried to seem theoretically sophisticated by using concepts (or at least words) derived from structuralism and post-structuralism. ${ }^{28}$ Many of these historians rightly worry that Thompson's naive empiricism tacitly assumes that the individual agent has pure experiences uncorrupted by the effects of power. But they wrongly conclude that the proper alternative is a theory that gives pride of place to concepts of language or discourse that neglect agency.

Structuralism and post-structuralism encourage historians to reify language. They suggest that meanings arise not from the ways agents use words but from the relations of difference among semantic units. The meanings of "male" and "working class" result not from the ways in which people use these words, but from the differences between these words and other words such as "female" and "middle class." Language thus appears to be a reified semiotic code that generates meaning quite apart from the activity of human beings. This reified view of language then reintroduces determinism and essentialism. A reified language determines the meanings, beliefs, and so actions of individual agents. And any particular language consists essentially of a particular set of relationships among its semantic units.

By no means has every contributor to the new historiography been bewitched by a reified view of language. Yet, when historians do use post-structuralist concepts, their linguistic determinism and essentialism undermine their ability, respectively, to explain ideational change and to recognize the diversity of populism. Consider the problem of change. The new historiography ascribes to language a relative autonomy in relation to capitalism, thereby rendering problematic any direct appeal to experience as a source of change. When post-structuralists go on to reject the

${ }^{26}$ G. Stedman Jones, "The Determinist Fix: Some Obstacles to the Further Development of the Linguistic Approach to History in the 1990s," History Workshop (1996): 19-35.

${ }^{27}$ E. Thompson, "Poverty of Theory."

${ }^{28}$ Very little (if any) of the literature on postmodern and post-structuralist approaches to British social history is worth reading. The heatedness of the debate was matched only by its lack of philosophical literacy. For an overview, see W. Thompson, Postmodernism and History (Basingstoke, UK: Palgrave Macmillan, 2004), esp. chap. 6. 
"real," they undermine even indirect appeals to experience. Moreover, their emphasis on language as constitutive of all subjectivity undermines any appeal to agency as a source of change: if individuals merely construct their selves in terms given to them by a social discourse, they must lack the capacity to modify such discourses. When post-structuralists invoke reified languages as productive of both the social and agency, without in turn being produced by either of these, it is hard to grasp how and why languages might change. A related problem stems from the neglect of the diversity of populist discourse, or the confusion of diversity with difference. A reified concept of language encourages historians to look for a common set of meanings as opposed to the diverse beliefs that agents express in speech and action. Populism can act as little more than a broadening out of the concept of class. When post-structuralists do explore diversity, they generally do so in terms of the different connotations given to binary concepts by a reified language. Much less attention is paid to the diverse beliefs that agents hold for reasons of their own.

So, the new historiography is often caught between naive empiricism and reified concepts of language. What historians need is a theory that takes agency seriously while not reducing it to the pure experience of an independent social reality. The key idea here is that individuals are situated agents; they are agents who can act innovatively for reasons of their own, but their agency is situated in that they are necessarily influenced by social inheritances. The past consists of people and their activity. Languages and discourses do not exist as reifications. They are just abstract concepts that should refer back to the beliefs, utterances, and actions of particular individuals. When historians appeal to such abstract concepts, they might think about—and ideally specify—who precisely held the relevant beliefs. They might situate meanings more precisely in the relevant social ecology. And they might recognize that individuals may have held very different beliefs even if they used the same words-they might allow for diversity as well as binary differences.

To reject reified concepts of language is to highlight the importance of individuals and their activity. However, it is not necessarily to appeal to an autonomous subjectivity. Some post-structuralists set up a false dichotomy between, on the one hand, "theory" with its appeal to reified languages based on the difference among semantic units within them and, on the other, a naive empiricism that tacitly appeals to an autonomous subjectivity. Historians can escape this false dichotomy simply by insisting that agency is necessarily situated.

As agency is inevitably situated, so historians need a concept such as

The concept of tradition implies that people never can have pure experiences and unmediated knowledge. People necessarily encounter the 
world against the background of an inherited set of beliefs and meanings. Individuals construct their experiences and reach their beliefs influenced by inherited traditions. As the role of traditions is to situate agency, traditions should not be reified. Historians should not define traditions by reference to allegedly core ideas, and then locate people in traditions according to whether or not they hold these core ideas. Traditions are contingent and changing objects. They are products of individuals and their activity. Historians can specify the content of a tradition and trace its development only by following the ways in which people inherit and modify a loose collection of changing themes. So conceived, tradition is more than a tool of high intellectual history. It is an ontological concept that captures the social context of agency. Tradition is the background to all human activity. Tradition appears throughout social life, embedded in actions, practices, and social movements just as much as within texts.

A concept of tradition has the advantage over those of language and discourse that it allows for agency. Historians can conceive of change arising from the local reasoning of agents in the context of tradition. Yet, just as "tradition" captures the situated nature of agency, so historians need a concept such as "dilemma" to explain why agents modify traditions. A dilemma arises for individuals or groups whenever they adopt a new idea or action and so have to accommodate it in their existing beliefs and practices. Dilemmas here explain change without postulating a teleological process or a universal rationality. Dilemmas do not have historically necessary solutions. On the contrary, people respond to dilemmas in a creative and contingent process. The concept of a dilemma does not involve postulating pure experience of a prior social reality, and it also avoids dismissing the importance of lived experience. People modify traditions in response to their new beliefs irrespective of whether or not these beliefs reflect material changes in the world. Yet, people do have experiences of the world, and their interpreted experiences often constitute the dilemmas to which they respond. Just as tradition is more than a tool of high intellectual history, so dilemma provides a means of integrating language with the world. Beliefs and traditions are not reified discourses lurking in a detached linguistic realm uninfluenced by changes in the world. Beliefs and traditions are the properties and products of agents who revise them in response to historical dilemmas that often consist of interpreted experiences of social relationships.

\section{Socialism}

A new historiography could narrate the history of socialism in terms of a diverse cluster of ideas and the traditions and dilemmas from which they emerged. In doing so, it would raise questions about how to define 
socialism as an object of inquiry. The old historiography typically gave socialism stable content and then projected that content back through history. Sometimes socialism was defined by one or more core ideas, such as common ownership of the means of production. At other times it was defined as the ideological expression of a certain group, such as the working class. And at still other times it was defined by reference to an allegedly scientific theory of history and society. The general point is that the old historiography included an explicit or implicit account of the key features of socialism. Historians were able to define socialism in terms of the key features that their historiography ascribed to it.

How should historians define socialism after they reject the teleological and reductionist impulses of the old historiography? If socialism has no essence, how can historians decide whether something is part of a history of socialism? What working definition of socialism can guide the selection of organizations, authors, and texts for inclusion in any history of socialism? To focus on these questions, we might distinguish between two roles that are played by aggregate concepts such as tradition and dilemma. Aggregate concepts can be descriptive or explanatory. Historians can evoke socialism descriptively as an object of inquiry, but they also can evoke a socialist tradition as a background context to explain the beliefs and actions of particular socialists. When historians appeal to an explanatory concept, they can offer a pragmatic justification of its content. They can say that they define a tradition one way rather than another, to include these things but not those, because doing so best explains the particular objects that they want to explain. Clearly, however, when historians appeal to a descriptive concept that does not do explanatory work, they cannot define it pragmatically by reference to what they want to explain. The problem is, therefore, not how to define this or that tradition of socialism so as to explain something; it is how to define socialism in order to describe an object of inquiry.

This problem arises insofar as the new historiography rejects essentialism and so reified definitions of socialism. Socialism has no necessary core. There are no ideas and actions such that when they are present, we have an instance of socialism, and when they are absent, we do not have an instance of socialism. On the contrary, socialism is a fluid set of beliefs and practices that people are constantly making and remaking and in which no one idea or action has a fixed or necessary place. Historians can define socialism only by tracing how it develops over time as its exponents inherit, debate, and modify beliefs and practices before passing them on to others. Of course, people often try to stipulate what is and is not socialism, to dismiss a person or group for being socialist or for not being properly socialist, but these stipulations are just part of political struggles involving words and their meanings. There is no "true socialism" against which to judge instances as proper or improper. Yet, if there 
is no "true socialism" by which to judge instances, then neither is there a true or natural definition of socialism by which to decide what organizations, authors, and texts to include in a history of socialism.

Perhaps the lesson is that historians should be more relaxed about defining their objects of inquiry. Maybe it is enough to say that we are inquiring into the organizations, authors, and texts that happen to have caught our attention or that happen to interest us. Be that as it may, I have tried in this book to be receptive to the ways in which British socialists understood themselves. My aim is to understand the British socialists of the late nineteenth century in their own terms-to recover the meanings of socialism for people who thought of themselves as socialists at a time before the political parties and global conflicts of the twentieth century arguably narrowed the range of meanings that were regularly associated with the word "socialist."

As the new historiography undermines stipulative definitions of socialism, it allows historians to pay greater attention to the varied ways in which past socialists have defined themselves. Instead of imposing a particular concept of socialism back on the past, historians might concentrate on recovering the various meanings, feelings, and ways of life that people have attached to socialism. The best way to grasp both the nature and the appeal of socialism is perhaps to portray it as a lived experience, or rather as an open-ended series of lived experiences. Socialism is not a given thing - a natural kind-with a prescribed and bounded content. Rather, socialists made plural socialisms by drawing on inherited traditions to respond imaginatively to cultural, social, and political dilemmas. Socialism emerged as diverse and fluid phenomena that included a vast range of beliefs, feelings, and activities. One task for historians is to recover the diversity of this movement-the different meanings it had for the people who were part of it.

When we take a more relaxed approach to defining objects of historical inquiry, we can allow that different histories of socialism can begin at different places. The word "socialism" derives from the Latin sociare, meaning "to combine" or "to share," and political thinking about community and fellowship has a very long history. Nonetheless, the word "socialism" emerged only after the French Revolution through the 1820 s and 1830s. At that time the Owenites became the first people in Britain to use the word self-consciously to describe themselves. Yet, after the

selves as "socialists," preferring a word such as "radical” or "republican." It was only later, beginning in the 1880 s, that terms such as "socialist" and "social democrat" began to gain wider currency in Britain. By the 1890s, numerous organized groups in Britain self-consciously avowed “socialism.” Different histories of British socialism might go back to early 
modern communal utopias, focus on the Owenites, or look at what has been called "the socialist revival" of the 1880 s.

This book focuses on the 1880s and 1890s. My narrative often stretches beyond those two decades, especially when I trace the later fortunes of various thinkers and groups. Even then, however, the relevant thinkers and groups are those that dominated British socialism in the 1880 s and 1890 s. I focus on the late nineteenth century because those years were the immediate context for the birth of the Labour Party. Although I do not try to narrate the formation of the Labour Party, I am interested in how different British socialists came to relate to it. My questions are about the diverse strands of British socialism that existed before the Labour Party and their relationship to the party. My story addresses questions such as: Which strands of socialism fed into the Labour Party? Which did not? What webs of meaning and actions did the Labour Party embrace? Which were forgotten or marginalized?

In selecting and arranging strands of British socialism during the $1880 \mathrm{~s}$ and the 1890s, I have again taken a relaxed and receptive approach. So, my division of British socialists into Marxists, Fabians, and ethical socialists is not an attempt to provide a formal classification in which each category is defined by an allegedly distinctive and defining set of properties. Of course, there are family resemblances among the members of each category, and those resemblances are typically greater than those across categories. Equally, however, there were heated disagreements within each category, and some members of each category had more in common with some members of other categories than they did with members of their own category. Each of these three categories is, like the more general category of socialism, a diverse and fluid movement, the character of which historians should not stipulate but rather recover by exploring the beliefs, feelings, and activities of the relevant people.

Far from stipulating a definition of Marxism, Fabianism, or ethical socialism, I try to recover the meanings of these categories for the people who belonged in them. The categories themselves arise from the selfunderstandings of late nineteenth-century British socialists. These categories constantly recurred in discussions of socialism and debates among socialists. British socialists typically saw themselves as Marxists, Fabians, or ethical socialists promoting a new religion, although several identified themselves with more than one of these categories, consciously locating themselves, for example, on the ethical wing of the Fabian Society.

The categories of Marxism, Fabianism, and ethical socialism have an additional advantage. They capture, more or less in chronological order, the self-understanding of the leading socialist groups that arose in Britain during the 1880 s and 1890 s. The first socialist groups to appear in Britain in the 1880s were Marxist-the Social Democratic Federation 
and the Socialist League. Next followed the Fabian Society, which arose out of the Fellowship of the New Life. Finally there emerged various groups-often located in the provinces-that explicitly set out to promote "the religion of socialism." In using the categories of Marxism, Fabianism, and ethical socialism, I am thereby able to embed the history of socialist thought in the history of socialist groups. Socialism was a set of ideas, but these ideas were embedded in organizations, practices, and ways of being. When I discuss individual thinkers, I generally do so because they were seen by fellow British socialists as the leading theorists of groups - the intellectual inspirations for personal transformations and collective actions.

\section{MAKING Socialism}

The Making of British Socialism traces the ways in which people collectively made various socialist projects in a complex world of mass literacy and popular politics. It explores the traditions against the background of which people turned to socialism and the dilemmas that prompted them to do so. It asks how people crafted and conceived of the diverse socialisms to which they adhered. Throughout, I concentrate on the period from 1880 to 1900 . The bulk of the book consists of three parts, each covering one of the main strands of British socialism recognized at that time, namely, Marxism, Fabianism, and ethical socialism. Each part contains four chapters dealing with the leading theorists and organizations of the relevant strand of British socialism. The aim is in part to narrate the rise of British socialism as a belief system that later gained some kind of expression in an organized party and a state formation. However, the aim is also to show how the diversity of British socialism was poorly captured by that party and state formation.

The next chapter explores the Victorian context in which people made British socialism. The Enlightenment and romanticism following rapidly on one another transformed early modern political thought with its republican humanism and natural jurisprudence. By the mid-nineteenth century, Enlightenment and romantic themes had intermingled in Britain to inspire a culture dominated by liberalism and evangelicalism. Liberalism, with its ties to classical political economy, and evangelicalism, with its basis in atonement theology, inspired ideals of individualism, laissezfaire, and free trade in public policy, as well as prudence, truth, and duty in personal and social relations. By the 1870s, however, this Victorian culture faced two major dilemmas: the collapse of classical economics and the crisis of faith. British socialism emerged largely in response to these dilemmas. The crisis of faith led people to break with evangelical- 
ism and to adopt ethical positivism and immanentist theologies that inspired moral emphases on humanitarianism and fellowship. The collapse of classical economics led people to explore new policy instruments and utopian visions.

Much of British socialism fused an ethic of fellowship with calls for society or the state to use new policies to improve the well-being of the poor. Equally, however, people with backgrounds in different traditions responded to the crisis of faith and the collapse of classical economics in various ways, thereby forging different socialisms, notably Marxism, Fabianism, and ethical socialism.

The first part of The Making of British Socialism discusses the Marxists. It highlights the continuing debt of Marxists to republican traditions with their vision of a popular and participatory democracy. Chapter 3 focuses on E. B. Bax, probably the leading socialist philosopher in Britain during the late nineteenth century. Bax argued that Marxism was an economic and historical science that lacked a philosophical and ethical basis. He wanted to base the Marxian dialectic on German idealism, arguing that the dialectic was a fact about reality. And he wanted to base an ethical defense of Marxism on the republican positivism of the French Revolution.

Whereas Bax fused Marxism with German idealism and republican positivism, H. M. Hyndman drew on a radical Toryism that overlapped with several republican themes. Hyndman founded and then dominated the Social Democratic Federation (SDF), the first socialist organization of the 1880s. Chapter 4 shows how Hyndman's discovery of Marx provided a scientific basis for his Tory historiography and politics, suggesting that they reflected both the economic laws governing capitalism and the dialectic of history. His Tory inheritance still lingered in his Marxism, inspiring a medievalist historiography, a fear of anarchy, a commitment to statesmanship, and a belief in peaceful social change.

Not every Marxist echoed republican themes. Yet, when other Marxists, notably William Morris, drew on other traditions that were skeptical of politics, they typically were pushed to the margins of the main Marxist organizations of the late nineteenth century. Chapter 5 highlights the place of romanticism and Protestantism in Morris's socialism. His romanticism led him to seek self-realization through an art based on naturalness and harmony. His Protestantism led him to do so in the everyday worlds of work and home. Morris inherited from John Ruskin a sociology

Even when Morris turned to Marxism, he still defined his socialist vision in terms of good art produced and enjoyed within daily life. His rejection of political action. 
Morris's purism attracted little support among the early Marxists largely because they drew on republican traditions that overlapped at key points with Hyndman's radical Toryism. Chapter 6 provides a detailed investigation of the background, thought, and politics of the members of the SDF. Several of the early members of the SDF were followers of James Bronterre O'Brien, based in the radical workingmen's clubs of London. Even after they came to accept the need for collective ownership of the means of production, their political strategy remained that of O'Brien. They believed in political action to create a properly democratic state through which the people might then promote social reforms. This account of the O'Brienites helps to explain various unsolved problems in the history of British Marxism, notably why most members remained with Hyndman rather than follow Morris into the Socialist League, and why the SDF adopted an ambiguous attitude to trade unions and palliatives.

The republican inheritance of many Marxists inspired a commitment to radical democracy. This commitment helps to explain why they came to have only a marginal and oppositional role in British socialism. British socialism soon became dominated by more liberal concepts of democracy. The second part of The Making of British Socialism explores the principal source of this liberalism: Fabianism. As the Fabian Society broke away from the Fellowship of the New Life and rejected Marxism and anarchism, its leading members reworked liberal radicalism to respond to the collapse of classical economics.

Yet, Fabianism contained diverse viewpoints that drew on different economic theories as well as, to varying degrees, Marxism and positivism. The early history of the Fabian Society saw lively disputes and compromises between those with different viewpoints and the political strategies that these inspired. Chapter 7 thus challenges the idea that there was a single Fabian socialism based on a shared theory of rent. The late nineteenth century saw numerous attempts to reformulate political economy. Different Fabians were attracted to marginalism, neoclassical theory, and more historical and ethical approaches. Their different analyses of economic surpluses inspired varying beliefs as to the extent to which the state could and should intervene either to redistribute these surpluses or to use them for the collective good.

Chapters 8 and 9 explore in more detail the thought of the two lead-

that became prominent later in the twentieth century. In the mid-1880s, 
Shaw shared many of the Marxist ideas of the SDF. Even later, after he rejected Marxist economics for marginalism, he continued to defend several Marxist themes in ways that distanced him from the other leading Fabians, most importantly Sidney Webb.

Webb was the single most important thinker and actor in the development of Fabian socialism. Chapter 9 looks in detail at his political thought, rejecting the often repeated claim that he was a descendant of the utilitarians and a representative of a new managerial class. Webb's intellectual background lay in the liberal radicalism of the 1870s, which combined ethical positivism with evolutionary sociology. Webb first became a socialist because of his positivist ethic. He soon defined his socialism in terms of an evolutionary philosophy. He later adopted collectivism when he turned away from neoclassical economics to positivist sociology. And his collectivism always remained an ethical ideal embedded in an evolutionary sociology.

Chapter 10 discusses Shaw's and Webb's respective political strategies and their roles in inspiring Fabian policy. The Fabians did not share a commitment to permeating other parties in order to promote incremental measures of socialism. For a start, Shaw would have liked an independent socialist party, but for much of the 1880s and 1890s he did not think that such a party was possible. Moreover, insofar as the leading Fabians came to agree on "permeation," they defined it differently. Shaw thought of permeation in terms of luring Radicals away from the Liberal Party in order to form an independent party to represent workers against capitalists. In contrast, Webb defined permeation in terms of giving expert advice to the political elite. The response of the Fabian Society to the formation of the Independent Labour Party (ILP) reflected the interplay of these different strategies.

The conference that formed the ILP was spearheaded by socialist groups from the north of England. Many of these groups were inspired by an ethical socialism. The third part of The Making of British Socialism describes the rise of ethical socialism and its relationship to the crisis of faith. Chapter 11 shows how various welfare liberals and ethical socialists adopted immanentism in an attempt to reconcile religion and science. They located God in evolutionary processes here on earth. They suggested that each person contains a divine spark and so is related to all others in fellowship. Many of them experimented with new ways of living in an attempt to realize the divine in themselves and in their relations with others and nature.

Chapter 12 highlights some of the themes that distinguish ethical socialism from welfare liberalism as well as other strands of socialism. Several ethical socialists owed a distinctive debt to American romantics such as Ralph Waldo Emerson, Henry David Thoreau, and Walt Whit- 
man. American romanticism initially entered British socialism through the wandering scholar Thomas Davidson, who inspired the Fellowship of the New Life. When Davidson continued on his travels, several of the socialists associated with the Fellowship took their ideals out of London and into the provinces. The most notable example was the libertarian poet Edward Carpenter, who set up the Sheffield Socialist Society and inspired numerous other local groups all across Britain, from Bristol to Nottingham and on to Bolton.

One of the most distinctive features of ethical socialism was the place it gave to personal transformation and communal utopianism. Chapter 13 explores the intersections between this type of socialism and a new anarchism. For most of the nineteenth century, anarchists were individualists, favoring clandestine organization and violent revolution. Yet, at the turn of the century, there arose a new communal anarchism associated with sexual liberation and moral experiments. The prophets of the new anarchism were Peter Kropotkin and Leo Tolstoy, not Mikhail Bakunin. Its organizational homes included the Freedom Group and the Brotherhood Church. It inspired agricultural and urban utopias in places such as the Cotswolds, Essex, Leeds, and London. And it appeared in discussion groups aimed at transforming personal and private relationships, including the Men and Women's Club.

Chapter 14 looks more closely at the main organizational expression of the religion of socialism, namely, the Labour Church movement. Previous historians have usually explained the rise of the Labour Church as part of a transfer of religious energy to the political sphere and then explained its demise by reference to the continuing process of secularization. In contrast, I focus on the religious self-understanding of the Labour Church. To begin, I explain the rise of the movement by reference to the immanentist theology with which so many Victorians and Edwardians responded to the crisis of faith. Thereafter, I appeal to the ideas of the movement in order to explain its appeal, structure, and activities and to suggest that the decline of the movement reflected the weaknesses of its theology as a political theory.

The final chapter explores the later roles of Marxism, Fabianism, and ethical socialism in the ILP, the Labour Party, and the social democratic state. The dominant strand of socialism fused Fabianism with ethical socialism. It promoted a labor alliance to win state power within a liberal, representative democracy, and then to use the state to promote social justice. Later in the twentieth century, the rise of modernist social science altered the type of knowledge on which the Labour Party relied, with Fabian approaches to the state and policy giving way to planning, Keynesianism, and other formal expertise. Whatever type of knowledge the Labour Party relied upon to guide state intervention, it was constantly 
challenged by socialists opposed to its liberal concept of democracy and the role it gave to the state. These latter socialists often advocated the democratization of associations within civil society itself.

Socialism arose as part of a broad cultural shift away from the evangelicalism and classical liberalism of the mid-nineteenth century, initially toward immanentism and social welfarism, and then on to the modernist approaches to public policy that became a prominent feature of the twentieth century. The rise and trajectory of socialism is thus part of a wider progressivism apparent in other movements such as the New Deal in the United States and the new liberalism in Britain. There is no clear boundary between socialists and other progressives, nor is there one "true" socialist view of justice and how to realize it. Some socialists have brought to progressivism a particular concern with class-based politics and state intervention. Others have brought different emphases on radical democracy and personal transformation. 